Bogusław Śliwerski*

\title{
„Spropagowany" pedagog społeczny jako uczony w przestrzeni politycznych konfrontacji
}

Ponad 75 lat temu Helena Radlińska opublikowała w „Przeglądzie Socjologicznym" aktualną dla współczesnych pedagogów społecznych notatkę do artykułu Andrzeja Waligórskiego ${ }^{1}$. Gdyby ta wybitna pedagog społeczna żyła i tworzyła dzisiaj, zapewne zamieściłaby ten tekst ponownie, jeśli nie w socjologicznym piśmie, to na pewno pedagogicznym. Historia bowiem zatoczyła koło i ponownie stajemy jako uczeni wobec tak istotnych czynników socjalizacyjnych, jak propaganda, agitacja i reklama w naszym codziennym życiu. Niestety, nie można o procesach społecznych zaśpiewać za Marylą Radowicz: „Ale to już było, i nie wróci więcej...”, gdyż było i wróciło. Świat polityki, także oświatowej, żyje propagandą i agitacją. Zakorzenieni w życiu podmiotów swoich badań naukowych oraz w podejmowaniu prób interwencji na rzecz zmiany społecznej osób wykluczanych, wykluczonych czy narażonych na to zjawisko pedagodzy społeczni dopiero po ponad ćwierćwieczu transformacji ustrojowej uświadomili sobie, że władze naszego kraju wykorzystały już na samym początku przemian gospodarczych i społecznych sytuację do niewidocznego dla obywateli przejmowania państwa, jego struktur, instytucji pod pozorem uczynienia ich środowiskami publicznymi, a w istocie częściowo do ich sprywatyzowania lub poddania ich etatystycznej kontroli i władztwu.

Powstały w 1989 r. stan pęknięcia, radykalnego odcięcia się polskiej humanistyki od monistycznej, zdegenerowanej ideologicznie pedagogiki socjalistycznej miał okazać się trwałym osiagnięciem czasów transformacji społeczno-politycznej, kulturowej i naukowej. Polska pedagogika stała się wraz z przełomem ustrojowym początku lat 90 . XX w. nauką zorientowaną na wartości pluralizmu i demokracji,

\footnotetext{
* Uniwersytet Łódzki, Wydział Nauk o Wychowaniu, Katedra Teorii Wychowania.

${ }^{1}$ H. Radlińska, Propaganda, agitacja, reklama, „Przegląd Socjologiczny” 1938, t. VI, z. 1-2.
} 
na społeczeństwo otwarte, na różnice, wielość i obcość, na poszanowanie indywidualnej wolności i demokrację. Rok 1989 uwolnił tak ważną dla tego dyskursu przestrzeń wolności do uprawiania badań i upowszechniania ich wyników. Niestety, Polacy zajęci ratowaniem własnego bytu, odnalezieniem się w wolnorynkowych warunkach pracy, a w dużej mierze wciąż socjalistycznej płacy w instytucjach kontrolowanych przez rząd, nie wykorzystali możliwości demokratyzowania środowisk wychowawczych, opiekuńczych i specjalnej troski, oddając to pole kolejnym od 1993 r. rządom² . Sfera pozaszkolnych środowisk wychowawczych została w dużej mierze sprywatyzowana lub wyłączona z jakichkolwiek powinności rządu wobec kadr, a także infrastruktury placówek kulturalnych, oświatowych i opiekuńczych dla młodych pokoleń oraz osób starszych, zaś w szkolnictwie skutecznie zniechęcano do możliwego prawnie sprawowania nad nim społecznego nadzoru, a tym samym dopełnienia jego publicznych funkcji. Pedagodzy społeczni zupełnie stracili z oczu i zakresu własnych zainteresowań oraz wpływów właśnie tę sferę demokratyzowania edukacji szkolnej i pozaszkolnej, oświaty dla wykluczanych w neoliberalnych warunkach osób dorosłych i starszych.

W procesach rzekomego zainteresowania władz polskich budowaniem społeczeństwa obywatelskiego oraz odgórnego uspołeczniania szkolnictwa nie dostrzegano propagandowego zniechęcania obywateli i podmiotów edukacji do tych procesów, a nawet blokowania tych procesów dziesiątkami nowelizacji ustaw. Kolejno rządzący z różnych formacji politycznych - od lewicy poprzez centrum do prawicy - wykorzystywali agitację przeciwko własnemu społeczeństwu i deklarowanemu etosowi Polaka, jaki został stworzony przez ruch ,Solidarności”. Helena Radlińska wyjaśniała w swoim tekście, że wykorzystywana instrumentalnie przez władze do realizowania politycznych celów agitacja stanowi

[...] poruszenie mas dla uzyskania natychmiastowych wyników, bezpośrednie podniecanie do działań, pożądanych przez agitatora. W przeciwieństwie do propagandy agitacja częstokroć nie troszczy się o szerzenie poglądów, kształtowanie pojęć. Nie wyrabia, lecz narzuca. Nie interesuje się motywami, które mają przez czas dłuższy żywić się męką i nadzieją; chce natychmiastowego efektu. Dlatego spożytkowuje utarte skojarzenia, nawet myślowe błędy, przesądy. Nie prostuje nieporozumień, które mogą być chwilowo korzystne ${ }^{3}$.

Radlińska użyła określenia człowiek ,spropagowany”, by wskazać na tego, który jest określany tym mianem z tej racji, że jest „naszym facetem” (w gwarowym

${ }^{2}$ Szerzej w: B. Śliwerski, Szkoła na wirażu zmian politycznych. Bez cenzury, Oficyna Wydawnicza „Impuls”, Kraków 2012; tenże, Diagnoza uspołecznienia publicznego szkolnictwa III RP $w$ gorsecie centralizmu, Oficyna Wydawnicza „Impuls”, Kraków 2013; tenże, Edukacja (w) polityce. Polityka (w) edukacji, Oficyna Wydawnicza „Impuls”, Kraków 2015; tenże, R. Nowakowska-Siuta, Racjonalność procesu kształcenia. Studium z polityki oświatowej i pedagogiki porównawczej, Oficyna Wydawnicza „Impuls”, Kraków 2015.

${ }^{3}$ H. Radlińska, Propaganda, agitacja, reklama, s. 226. 
tego słowa znaczeniu - „urobionym”). To ktoś „,pewny”, kto nie zdradzi i będzie zachowywał się zgodnie z idea, którą przyjął za swoją. „Powinien być gotów do ofiary, nawet do zniesienia tortur. Przed niczym nie ulegnie, gdyż propaganda rozpaliła w nim ognisko, w żarze którego dusza jego zahartowała się jak stal. Żar uczucia ochroni go od hańbiącej rdzy słabości, od poddawania się wpływom otoczenia"4. Nie mogła przewidzieć, że w drugiej dekadzie XXI w. premier rządu, mianując nowych ministrów określi ich mianem ,zderzaków”, a więc zahartowanych w boju z opozycją urzędników, którzy będą bezwzględnie realizować cele już u podstaw sprzeczne $\mathrm{z}$ interesem obywateli, a w edukacji - z interesem dzieci i ich rodziców (np. jednym z nich było zmuszenie rodziców dzieci sześcioletnich do skierowania ich do nieprzygotowanych na to przyjęcie szkół podstawowych ${ }^{5}$ ). Premier Donald Tusk tak mówił w Pałacu Prezydenckim po wręczeniu nominacji nowym ministrom o ich roli, w tym o zadaniach minister edukacji:

- To jest rząd zderzaków, każdy z nas jest zderzakiem, ja też. Czy te zderzaki wytrzymają cztery lata, czy cztery miesiące? Zobaczymy. Idą ciężkie czasy, zdajemy sobie sprawę, jakie zadania sobie nałożyliśmy, więc każdy z nas jest zderzakiem. Nikt tu nie przyszedł z definicji na cztery lata, nikt. Każdy przyszedł wykonać swoją robotę. Nie da rady - szybciej się pożegna ze stanowiskiem ${ }^{6}$.

To jest klasyczny przykład „spropagowanego ministra” w piarowskim rządzie PO i PSL. Grzegorz Żurawski - rzecznik ministry edukacji Katarzyny Hall, a potem jej następczyni Krystyny Szumilas - zdradził kulisy „spropagowanej roli” w pracy Noś przy sobie statystyki, które możesz zmanipulować na swoja korzyść?

Pedagodzy włączyli się w walkę w sprawie sześciolatków między zantagonizowanym z władzą oddolnym ruchem rodzicielskim, silnie wspieranym przez polityków prawicy, konserwatystów, a ekspertami władzy (w tym głównie socjologami i psychologami) generującymi konkurencyjne teorie i diagnozy. Te ostatnie okazały się nieczytelne dla społeczeństwa mimo zmanipulowania przez ukrycie tego zjawiska pod szyldem tytułów naukowych psychologów, którzy są postrzegani jako naukowcy wyższego poziomu. Co gorsza, operowanie przez nich wiedzą na temat potrzeb i możliwości rozwojowych dzieci w wieku wczesnoszkolnym połączone $\mathrm{z}$ całkowitym brakiem wiedzy na temat warunków funkcjonowania edukacji szkolnej w Polsce jest naruszeniem nie tylko etyki, lecz także granic, których nie wolno im było przekroczyć. Wyobraźmy sobie sytuację odwrotna,

${ }^{4}$ Tamże, s. 225.

${ }^{5}$ B. Śliwerski, Polityczne uwarunkowania ,, bolszewizmu” w etatystycznej polityce oświatowej III RP, „Horyzonty Wyobraźni” 2015, nr 31, t. 14.

${ }^{6}$ Zderzaki - nowy rzad Tuska, http://wyborcza.pl/1,75478,10658922,Zderzaki_nowy_rzad_ Tuska_najmlodszy_w_historii.html (dostęp: 19.11.2011); Poczet ministrów za „Głos Nauczycielski” 2011 nr 46, s. 2 .

7 http://www.rp.pl/artykul/19,961582-MEN---tak-zle-jeszcze-nie-bylo.html?p=2 (dostęp: 20.11.2011). 
kiedy to profesorowie pedagogiki zaczęliby przekonywać społeczeństwo o tym, jak prowadzić terapię np. dzieci z zaburzeniami zachowań czy postaw, odwołując się do idei filozoficznych, praw dziecka czy teorii kształcenia/wychowania. Taka sytuacja byłaby niedopuszczalna i natychmiast obostrzona sankcją z tytułu przekraczania granic nauki i obowiązujących $w$ jej ramach kompetencji. Tymczasem nieznający szkoły psycholog, bo nieprowadzący w niej badań z zakresu kształcenia i wychowania, poucza w mediach pedagogów, jak należy to czynić, upewniając tym samym władze polityczne w słuszności jej rozwiązań, które nie mają nic wspólnego ani z troską o polepszenie sytuacji dzieci, ani też z profesjonalnym zapewnieniem im koniecznych warunków do rozwoju.

Rodzice jako naturalni wychowawcy stworzyli sieciową platformę „Ratuj Maluchy" w sytuacji, gdy akademicy nie byli obecni w mediach, zaś sporadycznie przywoływane przez dwie strony konfliktu wypowiedzi różnych pedagogów-ekspertów wzajemnie się wykluczały. Starania rodziców sześciolatków nie zostały poparte przez świat polityki i nauk pedagogicznych, gdzie ten ostatni obawiał się możliwości repulsji ze strony nadzoru pedagogicznego części refleksyjnych nauczycieli. Jak to zatem jest możliwe, że tak szeroko propagowana idea nauczyciela jako refleksyjnego praktyka czy intelektualnego transformisty nie znalazła ujścia $\mathrm{w}$ tej sytuacji? Co się stało z pedagogami społecznymi z środowisk akademickich? Gdzie są wyniki ich badań w ramach przygotowanych prac dyplomowych studentów czy rozpraw doktorskich, które zawierają konkretne dane empiryczne na temat stanu przygotowań szkolnictwa publicznego do planowanej przez MEN zmiany?

Weryfikowanie przez socjologów czy psychologów rzekomego wzrostu poziomu jakości wykształcenia dzieci na podstawie sondażu opinii rodziców budziło już tylko wyrazy politowania. Niestety, skoro rząd w latach 2008-2015 dostrajał swoją politykę do wyników sondaży opinii publicznej, to trudno, by inaczej podchodzili do tego problemu socjolodzy wyspecjalizowani w tego typu manipulacjach. Premierzy kolejnych rządów wszystkich stron politycznych oddawali ministerstwo edukacji narodowej w ręce albo ministrów, albo ich decyzyjnego aparatu władzy, o zaburzonych relacjach komunikacyjnych ze społeczeństwem, a załatwiających interesy dla siebie lub dla własnych środowisk partyjnych. W okresie transformacji edukacja nie stała się źródłem zachodzących w kraju przemian. Polski system powszechnej, obowiązkowej edukacji przedszkolnej i szkolnej nadal jest niedostosowany do:

1) przemian ustrojowych, gdyż nie jest demokratyczny ani nawet prodemokratyczny, konserwując typowy dla państwa totalitarnego centralistyczny układ nadzoru i zarządzania. Demokracja wymaga nie tylko społecznej, lecz także politycznej dojrzałości od absolwentów szkół, toteż niezmiernie ważne jest

${ }^{8}$ R. Przyborowska, Zaufanie do systemów eksperckich w edukacji, „Kultura i Edukacja” 2010, nr 1, s. 34 . 
przygotowywanie młodego pokolenia do odpowiedzialnego wyboru wartości i podejmowania zgodnie z nimi decyzji;

2) przemian społecznych, bowiem radykalnie lekceważy rodziców oraz prawnych opiekunów dzieci i młodzieży w sytuacji, gdy w świetle Konstytucji RP i ustawy o systemie oświaty szkoła ma pełnić rolę pomocniczą wobec rodziny. Traktowanie rodziców czy innych pozaszkolnych wychowawców jako pożytecznych partnerów jedynie w umacnianiu autorytetu nauczycieli, dyscyplinowaniu uczniów i wspomaganiu usługowo-materialnym pozbawia ich w tej placówce podmiotowego wpływu na przebieg procesów wychowawczych własnych dzieci;

3) przemian naukowych, gdyż lekceważy osiagnięcia nauk społecznych i humanistycznych w zakresie psychologii rozwojowej, uczenia się i pedagogiki szkolnej oraz porównawczej, ale też i ekonomicznych w zakresie hamowania rozwoju adekwatnej do nauk o zarządzaniu oraz socjologii kultury makrosystemowego i mikrosystemowego zarządzania instytucjami edukacyjnymi;

4) procesów glokalnych, głównie w zakresie nowych kultur komunikacji, powszechnego dostępu do źródeł informacji i wiedzy oraz włączania nowych technologii jako jednego z kluczowych narzędzi konstruktywistycznej dydaktyki.

$\mathrm{W}$ takiej sytuacji edukacja nie wyjdzie z dysfunkcjonalnych rozwiązań, destrukcyjnych ram i toksycznych procesów, gdyż proponuje się jej jedynie zamianę rozwiązań, które takimi wcale nie są i nie będą. Co gorsza, uderzają one w fundamentalny czynnik socjalizacji i wychowania dzieci i młodzieży, jakim jest rodzina. Oferuje się rozwiązania, które zupełnie pomijają zdefiniowaną w Konstytucji RP pomocniczą rolę szkoły wobec rodziny. Wspólnota partycypacji wychowawczej rodziców w szkole publicznej może powstać tylko wówczas, kiedy spełnione zostaną co najmniej trzy współzależne warunki, a mianowicie wzajemności, partnerstwa i jawności. Szkoła publiczna powinna być wspólnotą edukacyjna, w której procesy kształcenia i wychowania są kreowane przez nauczycieli traktujących edukację jako wspólne zadanie, gdzie powstają one w dialogu i partnerstwie uzgadniania zasad ich generowania oraz gdzie wśród samych pedagogów ma miejsce porozumienie i wzajemne poszanowanie.

Szkoła publiczna powinna być wspólnotą edukacyjna, w której procesy kształcenia i wychowania są kreowane przez nauczycieli traktujących edukację jako wspólne zadanie, gdzie powyższe procesy rodzą się w dialogu i partnerstwie uzgadniania zasad ich generowania oraz gdzie dochodzi wśród samych pedagogów do porozumienia i wzajemnego poszanowania. Uczący się nie wypowiedzą wówczas swoim nauczycielom posłuszeństwa i nie będą kwestionować normatywnego układu odniesienia skierowanych na nich oddziaływań pedagogicznych, jeśli nie doświadczą w szkole nie tylko własnego kryzysu tożsamości, lecz także kryzysu tożsamości swoich pedagogów oraz braku ich kompetencji komunikacyjnych. By każdego kolejnego roku nie marnować środków publicznych, polskiej oświacie potrzebna jest strukturalna, programowa i metodyczna rewolucja. 
Oświata i nauka nie są od tego, by reagować na doraźne sytuacje kryzysowe $\mathrm{w}$ państwie i doniesienia $\mathrm{z}$ różnego rodzaju sondaży diagnostycznych, w tym kreowanych przez podległe MEN ośrodki badań oświatowych, gdyż do procesu kształcenia i wychowania są wykształceni i ustawicznie uczący się profesjonalni pedagodzy, wychowawcy, nauczyciele i terapeuci.

Szkoły jako instytucje publiczne i niepubliczne nie są w stanie zmieniać społeczeństwa, gdyż są lustrzanym odbiciem jego przekonań i tradycji. Istnieją przy tym przeciwstawne orientacje co do celów edukacji szkolnej, bowiem część obywateli opowiada się za przystosowywaniem dzieci i młodzieży do akceptacji świata, z jego wszystkimi regułami, przymusami, ograniczeniami i przesądami na temat istniejącej kultury, inna zaś część oczekuje od szkół, by kształciły krytyczne umysły, wychowywały uczniów do niezależności i samodzielności z dala od konwencjonalnych klisz ich epoki i z wystarczającą mocą do społecznych przemian. W tej sytuacji rolą pedagogów społecznych jest prowadzenie niezależnych od władzy badań diagnostycznych, wyjaśniających, ale także podstawowych w zakresie konstruowania teorii i weryfikowania modeli eksperymentalnych, by dzięki nim możliwe było:

- prowadzenie racjonalnej polityki oświatowej/edukacyjnej w państwie przez (oby) oświeconych władców;

- uruchamianie czy wspomaganie sił społecznych, w tym organizacji pozarządowych;

- współpracowanie pedagogów ze środowiskiem projektującym i wytwarzającym nowe technologie i narzędzia komunikacji;

- alfabetyzacja w powyższym zakresie naturalnych i zastępczych rodziców czy opiekunów dzieci;

- kształcenie i doskonalenie kadr pedagogicznych w kraju.

Ruch obywatelskiego protestu w okresie PRL opowiedział się za modelem demokracji uczestniczącej, demokracji w ważnym sensie bezpośredniej, opartej na zinstytucjonalizowanej formie powszechnej, publicznej debaty społecznej - demokracji deliberacyjnej, debatującej. W tak projektowanym ustroju społeczno-politycznym oświata publiczna miała opierać się na trzech, ściśle powiązanych ze sobą zasadach - decentralizacji, samorządności i subsydiarności. Ład społeczny w szkole (z wyłączeniem podstaw programowych kształcenia i profesjonalnie realizowanej dydaktyki jako zastrzeżonych dla specjalistów) nie powinien być ustanawiany arbitralnie przez władze centralne, ale wypracowywany w dialogu podmiotów uczestniczących na rzecz koniecznej i wartościowej edukacji w społeczności oświatowej. Bez decentralizacji i samorządności szkolnictwa, bez autonomii szkół i ich uspołecznienia edukacja nie wyjdzie z głęboko zakorzenionych w systemie pozostałości „homosowietyzmu” i nie będzie w stanie sprostać konstruowaniu nowoczesnego i efektywnego kształcenia oraz wychowywania młodych pokoleń w naszym kraju.

Socjolog Piotr Gliński określa to, co się wydarzyło w Polsce po 1989 r., mianem zdrady elit w wyniku m.in. rozwiązania komitetów obywatelskich na rzecz 
„robienia” polityki w gabinetach władzy poza społeczeństwem. Wspólnoty obywatelskie muszą być wolne i niezależne od biznesu polityki, by mogły służyć społeczeństwu, jeśli ma się ono stać społeczeństwem obywatelskim. „Jeśli demokracja ma być żywa i odpowiadać na prawdziwe społeczne potrzeby, społeczeństwo musi być wolne i aktywne obywatelsko, nawet jeśli aktualnej władzy to nie odpowiada". Nota bene podobnie o tym zjawisku w odniesieniu do państw postsocjalistycznych pisze chorwacki filozof i krytyk kultury Boris Buden. Elity zapomniały o tym, co jest fundamentem całego społeczeństwa.

Nie chodzi o to, jak moglibyśmy w naszym społeczeństwie żyć lepiej, ale raczej o to, „Czym jest to, co czyni z nas członków społeczeństwa?” Czy jest tym społeczna sprawiedliwość, czy może tożsamość kulturowa, Bóg czy może własność prywatna, „nasze wartości” czy „ich zagrożenie”? W politycznej grze mieszczą się transcendentalne wymiary społecznego życia, które nie tyle dotyczą człowieka czy społecznych bytów, co uspołecznienia jego bycia ${ }^{10}$.

Tradycyjne uprawnienia państwa do realizowania zadań w przestrzeni publicznej w zakresie m.in. oświaty, nauki i szkolnictwa wyższego są przez każdą kolejną ekipę rządzących dekonstruowane na rzecz częściowego ich funkcjonowania $\mathrm{w}$ innym, bo skomercjalizowanym wymiarze przestrzeni instytucjonalnej. Tak stało się z opieką żłobkową, edukacją przedszkolną i szkolną, że pod pretekstem dofinansowania ich zadań ustawowych ze środków Unii Europejskiej z jednej strony promowano prywatyzację usług, $\mathrm{z}$ drugiej zaś - systematycznie redukowano środki w budżecie państwa, zmuszając placówki publiczne za pomocą mechanizmów rynkowych, do poszukiwania pozapublicznych środków pomocowych oraz odwołując się do innych niż administracyjne zasad regulacji. Na to wszystko nakłada się deformacja dyskursu publicznego, której źródłem staje się z jednej strony walka światopoglądowa, aksjonormatywna o kierunek rozwoju procesów wychowawczych młodych pokoleń, a z drugiej - ma miejsce manipulacja informacją oraz wiedzą i zamawianymi przez resort edukacji wynikami badań, które są konstruowane zgodnie z zasadą myślenia życzeniowego (wishfull thinking).

\section{Zdaniem Jadwigi Staniszkis:}

Władza relacyjna nie znikła jednak całkowicie, choć globalizacja doprowadziła do jej dekonstrukcji i nowych konfiguracji. Dawne państwo o wyraźnym centrum i hierarchicznie uporządkowanych, jednolitych logicznie procedurach już nie istnieje. Przekształciło się w państwo sieciowe (network state), z pajęczynami powiązań wysnuwającymi się często poza nominalne granice i ciążącymi ku zewnętrznym ośrodkom dyspozycji. Zdarza się też, że instytucje składające się na poszczególne pajęczyny zostały przejęte z układów o odmiennym poziomie rozwoju ${ }^{11}$.

9 Zdrada elit. Z prof. Piotrem Glińskim rozmawia Bronisław Tumitowicz, „Przegląd”, 19-25.08.2013, s. 10.

${ }^{10} \mathrm{~B}$. Buden, Konec postkomunismu. Od společnosti bez naděje k naději bez společnosti, Rybka Publishers, Praha 2013, s. 29.

${ }^{11}$ J. Staniszkis, Władza globalizacji, Wydawnictwo Naukowe Scholar, Warszawa 2003, s. 17. 
Do tych ostatnich niewątpliwie należała Polska Akademia Nauk, której władze ze zdumiewającą submisją oddały się w ręce ministerialnej władzy za cenę utrzymania własnego status quo. Nic dziwnego, że od początku ostatniej kadencji społecznie działający, a przecież wybierany w tajnych wyborach, Komitet Nauk Pedagogicznych jako jedyny stawił opór wobec żenujących praktyk biurokratycznego władztwa Akademii ${ }^{12}$.

Partycypacja jako delegowanie władzy na podwładnych ma na celu dopuszczenie ich do procesów planowania i podejmowania kluczowych dla podwładnych (członków danej społeczności, narodu, instytucji itp.) decyzji, rozpoznawania (diagnozowania) ich najważniejszych potrzeb, oczekiwań i interesów, opiniowania, kontrolowania stopnia oraz zakresu ich zaspokajania i realizacji przez sprawujących władzę oraz egzekwowania od niej pożądanej jakości. Uspołecznienie polityki oświatowej powinno skutkować rzeczywistym wprowadzeniem do ustroju szkolnego zróżnicowanych form oddolnej kontroli obywateli nad instytucjami oświatowymi, co miałoby na celu przeciwdziałanie biurokratycznym czy ideologicznym wynaturzeniom, umożliwianie partycypowania społeczności lokalnej w procesie zarządzania szkołami (finansowania, administrowania) i kreowania w nich procesu kształcenia czy wreszcie generowanie koncepcji reform.

Współczesne nauki społeczne dekodują ponowoczesny świat jako sprzyjający fragmentaryzacji tożsamości osób, jej rozproszeniu, a nawet jej inscenizowaniu. Nie można zatem podtrzymywać ustroju szkolnego minionego ustroju, opartego na systemie klasowo-lekcyjnym, selektywnego tak, jakbyśmy nadal mieli do czynienia z tamtym światem, gdyż działania władzy i nauczycieli będą nieskuteczne, bo nieadekwatne do wolności i pluralizmu, heterogeniczności i nieustannego inscenizowania różnicy. Internet zmienił świat, a świat zmienia Internet. Edukacja nie może być spóźnionym włóczęgą w sieci, toteż nie należy ograniczać się w szkołach do przekazywania wiedzy o mediach, genezie ich powstania i ewolucji, do normatywnych westchnień, alternatywnych utopii autoedukacyjnych, mnożenia sondażowych badań opinii na temat nowych technologii komunikacyjnych, by wzbudzać lęk przed doraźnymi, a marginalnymi czy możliwymi zagrożeniami dla dzieci i młodzieży. Młody człowiek potrzebuje pomocy w lepszym orientowaniu się $w$ istniejących i konfrontowanych z nim innych kulturach. Wychowanie i kształcenie powinny pomagać mu w radzeniu sobie z pluralizmem ludzkich kultur, rozumieniem ich oraz przełamywaniem poczucia niepewności czy bezpieczeństwa. W sytuacji rozpadu rodziny - szkoła musi stawać się bardziej familijna; z uwagi na niedostatek ruchu - powinna aktywizować uczniów; ze względu na zanik gier - powinna bawić; zaś w epoce multimedialnej - powinna wykorzystywać telewizor czy komputer jako medium do uczenia się.

${ }^{12}$ Dokumentacja próby odwolania przewodniczqcego KNP PAN w wyniku roszczeń MEN, „Rocznik Pedagogiczny” 2014. 
Pedagogika musi nauczyć się funkcjonowania w państwie, w którym jego funkcje w każdym z sektorów publicznych są realizowane przynajmniej częściowo w logice komercyjnej, a częściowo biurokratyczno-politycznej z radykalnym zarazem lekceważeniem roli ekspertów i gorsetem na jej uspołecznienie. Budzi to rzecz jasna wątpliwości co do sensu prowadzenia badań, skoro ich wyniki i tak nie są brane pod uwagę przez rządzących, ponieważ realizują oni własne interesy polityczno-administracyjne. W edukacji i nauce nie sprawdza się sprawowanie władzy na zasadzie dyscyplinowania i narzucania obywatelom oraz naukowcom procedur oraz rozwiązań instytucjonalnych, gdyż te sfery rządzą się wolnością. Każda redukcja autonomii wprawdzie gwarantuje władzy państwowej indywidualne profity do spłacania zadłużenia wobec własnych wyborców, ale zarazem niszczy oddolne inicjatywy, kreatywność i systemową zdolność do współpracy.

W III RP nie ma już spójnego systemu edukacyjnego. Posługiwanie się przez władze presją na zwiększanie procedur tylko po to, by było czegoś więcej i zarazem taniej dla budżetu państwa, jest demaskowane przez ekspertów jako nieadekwatne do wykluczających takie podejście procesów życiowych, w tym społeczno-rozwojowych i duchowych osób mających im podlegać w instytucjach edukacyjnych czy akademickich. Ośmiesza to sprawujących władzę i pozbawia ich mandatu funkcjonariuszy w służbie publicznej, szczególnie wówczas, kiedy na jaw wychodzi ich ignorancja i manipulacja środkami przekazu.

Jeśli następuje też - jak w postkomunizmie - odspołecznienie (ponieważ wymuszana przez globalne współzawodnictwo komercjalizacja zadań państwa osłabia społeczne poczucie współodpowiedzialności i chęć bezinteresownego uczestnictwa), a władza traci walor „polityki mocy” (w państwie sieciowym nikt nie posiada zdolności dokonywania radykalnego zwrotu, a największy wpływ ma - bezosobowa - logika globalna), pogłębia się jeszcze wrażenie pustki władzy i braku trwałych więzi społecznych ${ }^{13}$.

Stosowanie niejawnego publicznie, ale mającego przecież miejsce, subtelnego systemu karania przez ministrów edukacji narodowej czy nauki i szkolnictwa wyższego niepoprawnych politycznie, a nagradzanie personalnie i instytucjonalnie lojalnych, niestawiających oporu sojuszników, którzy nie kierują się prawdą naukowych odkryć, wiedza, ale obiecanymi korzyściami ekonomicznymi czy innymi, ukrytymi interesami, pogłębia procesy destrukcyjne, asymetrię między władzą a społeczeństwem, co będzie trudno naprawić. Tak można zarządzać produkcją towarów i usług, handlem czy transportem, ale nie stosunkami międzyludzkimi. Jednoznaczne hierarchie społeczne zanikają nie tylko w sposób naturalny, lecz także w wyniku nierównej walki politycznej, której celem jest pomniejszanie autorytetów i osłabianie rozpoznawalnych oraz uznawanych powszechnie statusów, jeśli te nie podporządkowują się procesom poprawności politycznej.

${ }^{13}$ J. Staniszkis, Władza globalizacji, s. 31. 
Jeżeli jeszcze sami rządzący nie są w stanie dostrzec nowych wymiarów władzy i trwają przy technikach pozbawionych już mocy sprawczej, to nie tylko stają się śmieszni (co dodatkowo niszczy relację władzy), lecz także szybko popadają w cynizm i ich polityka staje się pastiszem ${ }^{14}$.

Z makropolitycznych badań polityki oświatowej widać wyraźnie, że Ministerstwo Edukacji Narodowej nigdy nie wypracowało umiejętności metaregulacyjnych, które muszą być stosowane w sytuacji wielości „logik” instytucjonalnych, otwartego przepływu idei i dostępu społeczeństwa do wyników badań naukowych (także za pośrednictwem wiarygodnych ekspertów). Władze tego resortu nigdy nie doprowadziły do stworzenia społecznego „,mostu” porozumienia z narodem, który przecież de facto utrzymuje je, płacąc podatki, a nie mając prawa do sprawowania nad nimi społecznej kontroli. Nie istnieje żadne sprzężenie zwrotne między obywatelami a władzą oświatową gdyż to, które zostało wygenerowane, ma charakter usłużnej współpracy w standardzie posłuszeństwa u bezkrytycznej akceptacji poczynań władzy. Powoływane przez MEN zespoły opiniodawcze, takie jak Krajowa Rada Edukacji czy Forum Rodziców, okazały się ciałami ozdobnymi.

Od początku lat 90. XX w. ma miejsce ukryta dekonstrukcja warstwy normatywnej polskiej edukacji (demokracja, wartości chrześcijańskie, sprawiedliwość społeczna itd.) w postaci nieustannego dystansowania się wobec niej i udawania, że jest ona w procesie modernizacji kraju nieistotna, mimo że kierunek rozwoju państwa i społeczeństwa polskiego został zapisany m.in. w Konstytucji III RP i ustawie o systemie oświaty. Sprawiło to, że z jednej strony spory między władzą a opozycją na tle konfliktu wartości były nie tyle podstawą do uzgadniania wspólnego dla nich mianownika aksjologicznego, ile do wyostrzania różnic w momentach dla władz przełomowych, tzn. kiedy zbliżały się wybory parlamentarne, samorządowe czy do Europarlamentu lub gdy narastał niepokój społeczny (np. akcje obywatelskiego nieposłuszeństwa, referenda) na skutek radykalnej niezgody na proponowaną zmianę (m.in. obniżenie wieku obowiązku szkolnego). Obywatele doskonale zdają sobie sprawę z tego, że dowolna wymiana jakiegoś elementu w strukturze oświaty czy szkolnictwa wyższego nie ma dla nich neutralnego charakteru, bowiem dezorganizuje przestrzeń i organizację ich codziennego życia oraz pozbawia ich podmiotowości, współsprawstwa. Zarówno resort edukacji, jak i nauki i szkolnictwa wyższego nie dysponują strategią rozwoju polskiej edukacji, ale od podległych mu instytucji żąda podjęcia misji oraz posiadania wizji rozwoju.

Podobnie zresztą traktuje się w naszym kraju ekspertów, którzy są selekcjonowani ze względu na bezkrytycyzm i podejmowanie akcji wzmacniających władzę formalnym czy instytucjonalnym autorytetem. Władza powinna jedynie penetrować podległe jej środowisko, tzn. być obecną i harmonizować działalność instytucji oraz jej członków, a nie ujednolicać zasady ich funkcjonowania, gdyż

\footnotetext{
${ }^{14}$ Tamże, s. 30.
} 
żadna z nich nie może być uznana za uniwersalną. Jak słusznie pisze J. Staniszkis, najskuteczniejszym sposobem kontrolowania jest zarówno harmonizowanie porządku naturalnego ze sztucznym (normy, instytucje, prawo), jak i przede wszystkim opanowanie sztuki ,niedziałania"15. Znamy tę zasadę nie tylko z nauk o polityce, w których jedną z fundamentalnych dla władzy reguł budowania społeczeństwa obywatelskiego jest zasada pomocniczości państwa, nie zaś naruszającego integrację społeczną ucieleśniania idei naczelnej zgodnie z wizją partii-państwa jako władzy ${ }^{16}$. Podobnie jest z procesem wychowania, w którym najwyższą efektywność osiaga się dzięki stosowaniu tzw. „ukrytego”, pośredniego oddziaływania zawieszającego intencjonalność pedagoga ${ }^{17}$.

Brytyjski profesor socjologii Frank Furedi sformułował tezę o zaniku roli intelektualistów w ponowoczesnym świecie. Świat nauki okazał się zatem nie tylko w Polsce uległy wobec presji polityki, bezosobowej siły rynku, jego „niewidzialnej ręki” oraz instytucji publicznych, obniżając własne standardy na rzecz instrumentalnego i filisterskiego podejścia do życia. Wynika to z internalizacji przez ludzi wolnych zawodów, jakimi są akademicy i artyści, z kultury schlebiania, w wyniku której zastąpili własną autonomię, elitarność pójściem na łatwiznę przez podporządkowanie się zewnętrznym naciskom. Zdradzili zatem uniwersytety i szkoły, obniżając standardy wymagań wobec swoich studentów czy uczniów znudzonych realiami własnej edukacji. W pewnej mierze do upadku autorytetu nauki i uczonych przyczynił się relatywizm wiedzy humanistycznej i społecznej, która nigdy nie posiadała obiektywnego statusu. „Z pewnością odkąd kształcenie akademickie nie może rościć sobie prawa do tego, by być ścieżką wiodącą do prawdy, jego znaczenie uległo zmianie"18.

Podważanie autorytetu nauki zyskało już aprobatę także w naszym społeczeństwie, skoro w sprawach edukacji może być ekspertem każdy, kto tylko uczęszczał do szkoły lub ma w wieku obowiązku szkolnego dziecko albo wnuczka. Naukowcy potrzebni są władzy do upełnomocnienia własnej ignorancji, by dzięki nim obywatele nie dociekali już istoty i sensu podejmowanych decyzji politycznych. Wystarczy zatrudnić w każdej agendzie rządowej specjalistę od public relations, czyli od manipulowania danymi, by ten przywoływał właściwych ekspertów dla pozbawionej podstaw naukowych decyzji swoich przełożonych. Nie jest dla niego ważne, jaką informację ma przekazać społeczeństwu, gdyż musi ją po prostu sprzedać, tak jak handluje się towarami na rynku. Słusznie pisze Furedi:

15 Tamże.

${ }^{16}$ Zasada subsydiarności.

17 B. Śliwerski, Pedagogika ogólna. Podstawowe prawidłowości, Oficyna Wydawnicza „Impuls”, Kraków 2012.

${ }^{18}$ F. Furedi, Gdzie się podziali wszyscy intelektualiści?, przeł. K. Makaruk, PIW, Warszawa 2008, s. 11. 
Takie przekształcenie w produkt pozbawia wiedzę istotnej wartości i znaczenia: jako towar dostarczany przez domokrążców spod znaku ekonomii wiedzy staje się w istocie karykaturą samej siebie. Dlaczego? Dlatego, że bez związku z Prawdą wiedza nie ma żadnego istotnego znaczenia. Staje się pojęciem abstrakcyjnym, czymś, co łatwiej przekazywać, niż cenić i co można przetworzyć tak, by zyskało jak najbardziej przeciętny kształt ${ }^{19}$.

Nauka ma być użyteczna dla społeczeństwa, a kształcenie - ogólne dla rynku pracy. Stają się one przez to wartościami heterotelicznymi. Kto dzisiaj będzie pracował naukowo dla poszukiwania Prawdy, skoro prowadzenie badań wymaga koniecznych nakładów finansowych, a ich dysponentami są politycy, którzy uzależniają dostęp do środków od spełnienia instrumentalnych oczekiwań władzy. Nauki społeczne mają służyć inżynierii społecznej, socjotechnice władztwa politycznego, ekonomicznego, a także edukacyjnego. Każda próba wyjścia poza obowiązujące w państwie standardy czy kanon prędzej czy później prowadzi na margines, do wykluczenia albo rezygnacji z projektu badawczego lub wdrożeniowego. „Odkąd bowiem istota nauczania i sztuki przestała mieć sens społeczny, standardy zaczęły podlegać negocjacjom i łatwo podporządkowywały się celom pragmatycznym"20. Nauczyciel akademicki poddawany jest nieustannemu dewaluowaniu jego misji, profesjonalizmu, wartości czasu i nakładu pracy, inwestycji w siebie, traci na znaczeniu, również z tego powodu, że można na nim zaoszczędzić. Uczeni są zbytecznym kosztem, obciążeniem dla podatników, budżetu państwa, zmarnowaną inwestycją. Sprzyja to nie tylko negatywnej motywacji, lecz także obniżaniu standardów własnej pracy przez część kadr, skoro i tak nie docenia się ich roli. Patologiom akademickiego świata można byłoby poświęcić poważne studium badawcze, tylko po co, skoro naruszyłoby to tzw. interes społeczny, a więc (prze-)trwanie tysięcy osób zbytecznie zatrudnionych w szkolnictwie wyższym?

Im więcej jest państwa w państwie, im mniej możliwości podmiotów i instytucji do samoregulacji, tym szybciej jego władza traci zdolność do reprezentowania całości, wypierając etykę władzy na rzecz estetyki technokratycznej gry dla wtajemniczonych w nią jedynie funkcjonariuszy partii rządzącej, często z pominięciem koalicjanta, jeśli takowy jest. Potwierdzanie przez media i elity społeczne niezdolności urzędujących ministrów i ich regionalnych odpowiedników do wiarygodnego komunikowania się ze społeczeństwem nie tylko wyklucza prawdę z wzajemnych relacji, lecz także staje się produkowaniem fałszu w obronie funkcjonalizacji patologii w zarządzanych strukturach, nie tylko władzy. Największym błędem, jaki popełniają kolejne ekipy rządzące w resortach edukacyjnych, jest nieumiejętność spojrzenia na publiczną przestrzeń oświaty i nauki z perspektywy makro, meta, niejako ,z lotu ptaka”, by nie tylko dostrzec, lecz także uwzględnić

\footnotetext{
19 Tamże, s. 13.

20 Tamże, s. 20.
} 
w procesach decyzyjnych wielość podmiotów i aktorów społecznych. Niestety, niezdolność kolejnych ministrów do odcentrowienia świata, a więc do zaniechania postrzegania swojej roli z perspektywy osobistej, prowadzi do egotycznych zachowań wobec krytyki jej pozamerytorycznych poczynań jako jedynie słusznych i korzystnych. Resorty edukacyjne nie poddały się - od momentu przyjęcia ustawy o systemie oświaty oraz ustawy o szkolnictwie wyższym - jakiejkolwiek autokorekcie, a nawet jej nigdy nie brały pod uwagę jako istotnego czynnika procesu transformacji politycznej, co musi pogłębiać z każdą zmianą parlamentarną destrukcję i niszczenie nawet racjonalnych projektów reform.

Zdumiewa mnie ta fascynacja nowymi pojęciami, które niektórzy odnajduja w tekstach zachodnich humanistów z drugiej połowy XX w., podczas gdy znacznie wcześniej przed nimi wprowadzali je do wyjaśniania procesów społecznych polscy pedagodzy, tacy jak np. Zygmunt Mysłakowski, który - na wiele lat przez Baudrillardem - posłużył się w swojej rozprawie o totalizmie pojęciem ,simulacra". Jak pisał w 1938 r.:

Dokoła pewnego typu wspólnoty urabia się legendę, zamieniając w ten sposób pewien fakt społeczny na mit społeczny. Takim nowoczesnym mitem stała się w naszych niemal oczach rasa; nieco wcześniej romantyzm dokonał heroizacji narodowości i narodu. Jaką rolę odgrywały te fakty w obrębie rzeczywistości dziejowej, a jaką mają odegrać ich mity, ich heroiczne simulacra. O ile działanie ich w dziejach było pozytywne i twórcze, o tyle jako mity nowoczesnego człowieka zwulgaryzowane i uproszczone, przynoszą zagładę cywilizacji ${ }^{21}$.

Jeśli pedagogika ma zachować to, co jest istotne w jej humanistycznym wymiarze, a więc podejmowanie działań poznawczych wyrażających ,[...] przeżywanie takich wartości, jak: prawda, obiektywizm, jasność myśli i jej wyrażania, spójność, krytycyzm, twórczość prowadząca do nowego poznania, racjonalność"22, to powinna trzymać się maksymalnie jak tylko jest to możliwe z dala od narzucania wszystkim określonej teorii czy modelu poznawczego jako niepodważalnego pewnika. Nie chodzi tu o ich kwestionowanie, ale o to, by uzyskiwane dzięki nim ważne poznawczo i praktycznie rezultaty nie wykluczały innych podejść badawczych z ich odmiennymi przesłankami teoretycznymi, skoro „,[...] nie fakty obalają teorie, lecz teorie produkują fakty. Nie istnieje nie ukierunkowana teoretycznie obserwacja. Dane gromadzi się dla podtrzymania hipotezy. Nauka nie objawia „prawdy”, ponieważ widzi tylko to, co jej metody, techniki i narzędzia pozwalają zobaczyć"’3.

Komercjalizacja i ponowna polityzacja nauk pedagogicznych wynika z ich kryzysu instytucjonalnego i personalnego. Odeszło pokolenie znaczących

${ }^{21}$ Z. Mysłakowski, Totalizm czy kultura, Spółdzielnia Wydawnicza „Czytelnik”, Kraków 1938, s. 31-32.

${ }^{22}$ J. Kubin, Kultura intelektualna, Dom Wydawniczy Elipsa, Warszawa 2005, s. 21.

${ }^{23}$ Tamże, s. 24. 
humanistów myśli o wychowaniu i kształceniu, m.in.: Bogdan Suchodolski, Stefan Wołoszyn, Wincenty Okoń, Tadeusz Nowacki, Mieczysław Łobocki, Czesław Kupisiewicz, Kazimierz Denek. Inni zaś, do niedawna tak znaczący liderzy pedagogiki, jak: Tadeusz Lewowicki, Czesław Banach czy Heliodor Muszyński, są już - z racji wieku czy innych preferencji życiowych - poza bieżącym dyskursem naukowym. Jeszcze utrzymują aktywny kontakt z pedagogiką przedstawiciele najstarszej generacji - Irena Wojnar czy Józef Półturzycki. Kluczowe pozycje w wyższym szkolnictwie niepublicznym zajmuje postkomunistyczna profesura, która jest $\mathrm{w}$ dużej części zainteresowana już jedynie przetrwaniem i powiększeniem emerytury niż rozwijaniem wiedzy. Co gorsza, jej postawy stają się wzorem dla młodych pokoleń badaczy, które uznają jej reguły postępowania za właściwe.

O podobnej sytuacji piszą prawnicy:

[...] to właśnie ci ludzie, zajmując czołowe stanowiska w instytucjach naukowych, nadal skutecznie bronią pozytywistycznego paradygmatu, blokują rozwój nowych, „nieprawomyślnych” programów badawczych i tworzą takie normy poprawności politycznej, które praktycznie uniemożliwiają krytyczne badania bardzo wielu faktów [...]. W końcu to opanowany przez postkomunistycznych profesorów Trybunał Konstytucyjny zatrzymał w Polsce oraz w wielu innych krajach bloku postsowieckiego lustrację i dekomunizację i to postkomunistyczni profesorowie zreformowali polską gospodarkę w taki sposób, że postkomunistyczna nomenklatura stała się właścicielem ogromnej części majątku narodowego. Jest paradoksem transformacji ustrojowych w naszej części Europy, że rządy się w nich zmieniają, a ukryta za murem akademickiej autonomii postkomunistyczna profesura jest wieczna oraz nietykalna i w ten sposób wczorajsi grabarze demokracji i rządów prawa stają się dzisiaj jej strażnikami. Co gorsza, to właśnie oni kształtują etos młodych badaczy, którzy w swej większości stają się równie tchórzliwi i zakłamani, co ich komunistyczni wychowawcy ${ }^{24}$.

Możemy w tym kontekście pytać o to, kim byli ministrowie edukacji III RP czy ministrowie nauki i szkolnictwa wyższego oraz o powody podtrzymywania także z udziałem środowisk akademickich i edukacji światopoglądowych podziałów w naszym kraju.

Swoisty impas instytucjonalny akademickiej pedagogiki w zakresie prowadzenia badań podstawowych objawia się w tak kluczowych subdyscyplinach, jak: dydaktyka, pedagogika ogólna czy teoria wychowania, których zadaniem jest przecież wytwarzanie wiedzy naukowej ze względu na czysto poznawcze cele, w przeciwieństwie do tych subdyscyplin pedagogiki, którym jest bliżej do nauk stosowanych, a więc bardziej użytecznych, przydatnych praktyce kształcenia i wychowania. Ich byt jest zagrożony $z$ tego właśnie powodu, że nie spełniają w wyniku komercjalizacji nauki kryterium bezpośredniej użyteczności praktycznej. Tymczasem żywiołem uniwersytetu powinno być „to, co społeczne, a nie to,

${ }^{24}$ L. Morawski, Kryzys teorii prawa oraz innych nauk prawnych $w$ Polsce $i$ gdzie indziej, „Prawo i Więź” 2013, nr 2(4), s. 32. 
co państwowe"25. Pedagogika akademicka, uniwersytecka ma służyć społeczeństwu, narodowej kulturze, a nie „polityko-techno-biurokratycznej” działalności władzy, która usiłuje nas zamknąć w kleszczach tego, co jest próbą wymuszania dostosowywania się nauki do instrumentalnych celów rządzącej partii politycznej.

Nie mam na uwadze lekceważenia władzy, polityki i polityków, gdyż świat nauki istnieje i rozwija się także dzięki stwarzanym przez nich warunkom makroekonomicznym, ale nie można rezygnować z tendencji emancypacyjnych wobec świata instytucji, by służyć ludzkości, a nie krótkotrwałym koalicjom czy ruchom politycznym.

[...] podstawą pracy uniwersytetu, podobnie jak podstawą naszego bycia - razem, jest troska o człowieczeństwo jako niezbędną, nieodzowną i niezbywalną otulinę, która dopiero umożliwia satysfakcjonujące pełnienie funkcji zawodowych. [...] Stosunek uniwersytetu do instytucji polityko-techno-biurokracji nie polega na zanegowaniu ich istnienia i pracy, lecz na rozważnym i nieprzerwanym krytycznym analizowaniu i, w konsekwencji, na przeciwstawianiu się narastającej fali ekspansji tychże struktur na teren tego, co społeczne $[\ldots]^{26}$.

Bliższe jest mi jednak spojrzenie Tadeusza Sławka, który w trosce o rację istnienia uniwersytetu tak pisze o jego roli: „Uniwersytet jest zatem szczególną formą zaangażowania w świat «przeciwko światu», w którym człowiek działa i pracuje. Tworzyć świat w rozumny sposób można jedynie, uzyskując należyty od/do niego dystans, i uniwersytet jest miejscem takiego dystansowania się"27. Jeśli bowiem to, co rytualne jest zastępowane tym, co polityczne, to uniwersytet „podporządkowany jest władzy politycznej, decydującej w rzeczywistości o tym, który aspekt rozumu i wolności może być urzeczywistniony"28.

Pojawiają się nowe problemy w edukacji i dla edukacji, wśród których niewątpliwie na pierwsze miejsce wysuwa się już nie uzależnienie od używek, agresja w środowisku szkolnym i pozaszkolnym, ale niepowodzenia młodych ludzi w radzeniu sobie z rzeczywistością i iluzją osamotnionego lub pozornie wspólnotowego życia w cyberprzestrzeni.

Stawia to nowe wyzwania także przed pedagogiką, ale aby mogła ona je podjać, musi sobie już nie tylko odpowiedzieć na pytanie: „Jakiego człowieka powinna edukować?”, ale też: „Jak człowiek będzie sobie radził z ograniczeniami i wyzwaniami płynącymi z dwóch światów - świata rzeczywistego i świata iluzji?" Czy ma to być homo informaticus, czy raczej homo creator, a może - jak proponowała Teresa Borowska (1998) - homo construens? ${ }^{29}$

${ }^{25}$ T. Sławek, Uniwersytet-pożytki i powinności, „Nauka” 2013, nr 2, s. 11.

${ }^{26}$ Tamże, s. 13-14.

${ }^{27}$ Tamże, s. 15.

${ }^{28}$ Tamże.

${ }^{29}$ H. Krauze-Sikorska, M. Klichowski, Świat Digital Natives jako wyzwanie pedagogiczne - kilka refleksji zamiast zakończenia, [w:] H. Krauze-Sikorska, M. Klichowski, Świat Digital Natives. Młodzież w poszukiwaniu siebie i innych, Wydawnictwo Naukowe UAM, Poznań 2013, s. 183. 
Jak na razie potrafimy jedynie opisywać pewne zdarzenia i sytuacje, ale brak jest w pedagogice eksperymentów, badań w działaniu, które pokazywałyby zdolność pedagogów do radzenia sobie w sytuacjach zdiagnozowanych już problemów egzystencjalnych osób będących w zasięgu ich wpływów.

Wychowanie, edukacja, kształcenie od wieków były związane z kulturą jako fundamentalnym warunkiem ludzkiej egzystencji. W Polsce nie powiodło się powiązanie pedagogiki i przedmiotu jej badań z kulturą, także na poziomie instytucjonalizacji władzy. Odrębnie istnieją ministerstwa: kultury i dziedzictwa narodowego, edukacji narodowej, szkolnictwa wyższego i nauki oraz sportu, toteż trudno się dziwić, że ani edukacja, ani nauka, ani szkolnictwo wyższe, nauka i kultura fizyczna nie są ze sobą integralnie związane. Pedagodzy mówią o socjalizacji, inkulturacji, kształceniu czy pielęgnacji człowieka, ale jako zupełnie odrębnych formach ludzkiej aktywności, profesjonalnych oddziaływaniach i społecznych wpływach. Tymczasem to, jak się komunikujemy, jakie rozwiązujemy problemy na co dzień, jak podróżujemy, jak funkcjonuje władza, jak się odżywiamy, jak ubieramy itd. składa się na ludzką kulturę. Można mieć nadzieję, że w praktyce czytania i pisania przez pedagogów społecznych wytworzy się wspólnota ludzi kultywujących i praktykujących podstawowe, a ponadczasowe wartości absolutne, jakimi są dążenia człowieka do prawdy (poznania), dobra (moralności), piękna (estetyki) i transcendencji. Wówczas lepsza będzie nie tylko szkoła, lecz także pozostałe środowiska socjalizacyjno-wychowawcze.

\section{Bibliografia}

Buden B., Konec postkomunismu. Od společnosti bez nadĕje k nadĕji bez společnosti, Rybka Publishers, Praha 2013.

Dokumentacja próby odwołania przewodniczacego KNP PAN w wyniku roszczeń MEN, „Rocznik Pedagogiczny" 2014.

Furedi F., Gdzie się podziali wszyscy intelektualiści?, przeł. K. Makaruk, PIW, Warszawa 2008.

Krauze-Sikorska H., Klichowski M., Świat Digital Natives jako wyzwanie pedagogiczne - kilka refleksji zamiast zakończenia, [w:] H. Krauze-Sikorska, M. Klichowski, Świat Digital Natives. Młodzież w poszukiwaniu siebie i innych, Wydawnictwo Naukowe UAM, Poznań 2013.

Kubin J., Kultura intelektualna, Dom Wydawniczy Elipsa, Warszawa 2005.

Morawski L., Kryzys teorii prawa oraz innych nauk prawnych w Polsce $i$ gdzie indziej, „Prawo i Więź” 2013, nr 2 (4).

Mysłakowski Z., Totalizm czy kultura, Spółdzielnia Wydawnicza „Czytelnik”, Kraków 1938.

Przyborowska R., Zaufanie do systemów eksperckich w edukacji, „Kultura i Edukacja” 2010, nr 1.

Radlińska H., Propaganda, agitacja, reklama, „Przegląd Socjologiczny” 1938, t. VI, z. 1-2.

Sławek T., Uniwersytet - pożytki i powinności, „Nauka” 2013, nr 2.

Staniszkis J., Władza globalizacji, Wydawnictwo Naukowe Scholar, Warszawa 2003.

Śliwerski B., Diagnoza uspołecznienia publicznego szkolnictwa III RP w gorsecie centralizmu, Oficyna Wydawnicza „Impuls”, Kraków 2013.

Śliwerski B., Edukacja (w) polityce. Polityka (w) edukacji, Oficyna Wydawnicza „Impuls”, Kraków 2015 . 
Śliwerski B., Pedagogika ogólna. Podstawowe prawidłowości, Oficyna Wydawnicza „Impuls”, Kraków 2012.

Śliwerski B., Polityczne uwarunkowania , bolszewizmu” w etatystycznej polityce oświatowej III RP, „Horyzonty Wyobraźni” 2015, nr 31, t. 14.

Śliwerski B., Szkoła na wirażu zmian politycznych. Bez cenzury, Oficyna Wydawnicza „Impuls”, Kraków 2012.

Śliwerski B., Nowakowska-Siuta R., Racjonalność procesu ksztatcenia. Studium z polityki oświatowej i pedagogiki porównawczej, Oficyna Wydawnicza „Impuls”, Kraków 2015.

Zdrada elit. Z prof. Piotrem Glińskim rozmawia Bronisław Tumiłowicz, „Przegląd”, 19-25.08.2013.

\section{Netografia}

http://www.rp.pl/artykul/19,961582-MEN---tak-zle-jeszcze-nie-bylo.html?p=2 (dostęp: 20.11.2011). Zderzaki-nowy rzad Tuska, http://wyborcza.pl/1,75478,10658922,Zderzaki_nowy_rzad_Tuska najmlodszy_w_historii.html (dostęp: 19.11.2011); Poczet ministrów za „Głos Nauczycielski” $2011 \mathrm{nr} 46$, s. 2. 